\title{
The Constitutional Landscape after the Fourth and Fifth Amendments of Hungarian Fundamental Law*
}

\begin{abstract}
IMRE VÖRÖS
Abstract. The essay analyses the fourth and fifth amendments of the Hungarian Fundamental Law with special respect to the opinion of the Venice Commission and the resolution of the European Parliament. It will be pointed out that the fourth amendment transferred several legal regulations into the Fundamental Law which were previously qualified as unconstitutional by the Hungarian Constitutional Court. The Fundamental Law contains at the same time the declaration of a fundamental right and the unconstitutional limitation of it by the latter regulation. The inconsistency is evident, therefore the Constitutional Court has to choose in the future between the contradictory constitutional regulations. A possibility to solve this dilemma could be the separation of the legal norms of the constitution as lex generalis (e.g. rule of law, human dignity) and lex specialis which could not derogate the lex generalis, and cannot be applied accordingly.
\end{abstract}

Keywords: amendment of the constitution, constitutionalism, democracy, Constitutional Court, in consistency of the constitution, limitation of fundamental rights, Venice Commission

I.

\section{INTRODUCTORY REMARKS}

1. In terms of Hungarian constitutional law and the public law system, 2013 seemed to be as eventful as the previous three years of the country, which had brought radical changes in the constitutional system. The Fourth Amendment of Fundamental Law (Vincze 2012) passed on March 25, 2013 - was reviewed by a Constitutional Court decision on May 24, 2013, which was quickly followed by the Opinion of the Venice Commission on June 17 and lastly the European Parliament passed a Resolution on the situation of fundamental rights: standards and practices in Hungary (July 3, 2013). ${ }^{1}$ Then in September 2013, the Fifth Amendment of Fundamental Law was passed, only six months after the Fourth.

2. It is of no coincidence that the situation of Hungarian constitutionality is within the focus of the European Council and European Parliament again: now the time is ripe to

* This article was founded by Alexander von Humboldt-Stiftung.

1 12/2013 (V. 24) AB decision (May 21, 2013); Opinion 720/2013 (17 June 2013) on the Fourth Amendment to the Fundamental Law of Hungary. Adopted by the Venice Commission at its 95th Plenary Session (Venice, 14-15 June 2013). <<http://www.venice.coe.int/WebForms/documents/by_ opinion.aspx >>; European Parliament resolution of 3 July 2013 on the situation of fundamental rights: standards and practices in Hungary (pursuant to the European Parliament resolution of 16 February 2012) <<http://www.europarl.europa.eu/sides/getDoc.do?pubRef=-//EP//TEXT+TA+P7-TA-2013$0315+0+\mathrm{DOC}+\mathrm{XML}+\mathrm{V} 0 / / \mathrm{HU} \&$ language $=\mathrm{HU}>>$

Imre Vörös, Member of the Hungarian Academy of Sciences (Budapest)

(Received: 30.09.2013; revision received: 15.11.2013; accepted: 24.01.2014) 
conduct a thorough review of the trends of constitutionality, instead of the review of one single norm, its constitutionality or violation of international treaties; hence the analysis of the whole issue instead of parts of it. The Venice Commission conducted several investigations regarding the Hungarian legislature, but for the European Parliament, it was the first occasion. Regarding the basis of the parliamentary resolution, the report of the Committee on Civil Liberties, Justice and Home Affairs, the so-called Tavares-report (named after the head of the Committee) can be mentioned. ${ }^{2}$

The comparative nature of this review of the event period - in terms of constitutional issues - is justified by the fact that the two reports have overlapping subjects, even though the inquiries were of different magnitudes.

II.

\begin{abstract}
OPINION OF THE VENICE COMMISSION AND THE RESOLUTION OF THE EUROPEAN PARLIAMENT - THE ROAD OF THE HUNGARIAN PARLIAMENT TO THE FIFTH AMENDMENT OF FUNDAMENTAL LAW
\end{abstract}

\title{
A) The Opinion and Resolution
}

1. Though the Hungarian Government willingly and often labels Hungarian Fundamental Law as being "steady as granite", ${ }^{3}$ coming to its fifth amendment it rather proves to be "soft as cow dung". The advisory body of the Council of Europe: the Venice Commission adopted its opinion regarding the Fourth Amendment to Fundamental Law (see Vincze 2012) (hereinafter: Opinion), but by the time summer had passed, a new Fifth Amendment to Fundamental Law had been passed - partly reflecting the Opinion and critique received from Hungarian legal literature. ${ }^{4}$ Membership in the Council of Europe - thus accession to

2 No. of the Report: A7-0229/2013.

$3<<\mathrm{http} / / / \mathrm{m} . \mathrm{mandiner} . \mathrm{hu} / \mathrm{cikk} / 20120102$ orban_granitszilardsagu_az_alaptorveny $>>$

${ }^{4}$ Chronowski, N.-Csatlós, E.: Juidicial Dialogue or National Monologue? ELTE Law Journal 2013/1. http://papers.ssrn.com/sol3/papers.cfm?abstract_id=2332172; Zeller, J.: Nichts ist so beständig... Die jüngsten Novellen des Grundgesetzes Ungarns im Kontext der Entscheidungen des Verfassungsgerichts. Osteuropa Recht 2013/3. 307-325; Vörös, I.: Az alkotmányban korlátozott alapvető jogról és az ilyen alkotmányról. Glossza az Alaptörvény negyedik módosításához (On the fundamental right limited in the constitution itself and on such a constitution. Glossa to the fourth Amendment of the Fundamental Law) http://fundamentum.hu/sites/default/files/vorosi_korkerdes.pdf. 2013.05.15; joint expert opinion of the Hungarian Helsinki Committee, Eötvös Károly Policy Institute and Hungarian Civil Liberties Union on the Fourth amendment, see http://helsinki.hu/wp-content/ uploads/Appendix_1_Main_concerns_regarding_the_4th_Amendment_to_the_Fundamental_Law_ of_Hungary.pdf; Halmai, G.: Constitutionalism in Hungary: Undermining the Fundamental Law. JURIST - Forum, April 12. http://jurist.org/forum/2013/04/gabor-halmai-hungary-churches.php; Antal, A.: Alkotmányozási korszakok és technikák (Constitutional eras and techniques). Közjogi Szemle 2013/2; Smuk, P.: Ostrom vagy felújítás alatt? A véleményszabadság új határai (Siege or under renovation? New limits of the freedom of speech). Közjogi Szemle 2013/2; Orbán, E.: Az Alaptörvény paradoxonjai. Átmenetböl? Átmenetbe! (Paradoxons of the Fundamental Law. From Transition? To Transition!) Közjogi Szemle 2013/2; Kazai, V.: Kettős nyomás alatt (Under double pressure). Közjogi Szemle 2013/3. 
the European Convention on Human Rights, ${ }^{5}$ protected by the Council - is a condition for accession into the EU; a condition that Hungary has long ago fulfilled. ${ }^{6}$ The Commission has already drafted opinions related to Hungary, such as the opinion regarding the drafting of the new Fundamental Law and its legislative process. ${ }^{7}$ This time again, the Commission targeted its investigation to supervise, whether the legislation of the Member State is compatible with the European Convention on Human Rights and the Statute of the Council of Europe. These are based on three foundations: respect for human rights, democracy and rule of law, including but not limited to independence of judiciary. ${ }^{8}$

2. The Fourth Amendment came to the docket of the Commission for two reasons: first, the Secretary-General of the Council of Europe called for investigation, and second, because of the Hungarian Government itself. The Commission sent a five-member panel of experts from among its members, which met with the representatives of government, Parliament, political parties, public organizations, and experts, during April 2013. A second meeting was held in Vienna; apart from the delegation of the government, representatives of experts - commissioned by the Hungarian Government for reviewing the Fourth Amendment - took part in that meeting. ${ }^{9}$ Then this expert panel of the Commission sent its draft to the Hungarian government for consideration, which reacted and applied for an adjournment of the review, arguing that the panel should wait for those particular Acts and other laws to be passed due to the Fourth Amendment.

The Government reaction surprised the panel of experts: they expressed their opinion that their mandate covered the review of the Fourth Amendment, not the legislation subsequent. ${ }^{10}$ Were they to wait for the subsequent legislation, the Hungarian Constitutional Court would be bound to review these laws in light of the Fourth Amendment, though serious doubts were raised regarding the Fourth Amendment itself. For that matter, the Hungarian Government requested the consideration of the Fourth Amendment - as I mentioned supra.

3. After final modifications, the document prepared by the panel was adopted on the June $14^{\text {th }}-15^{\text {th }}, 2013$ meeting of the Venice Commission, and was sent to the Council of Europe and the Hungarian Government.

The Opinion examines the regulations of the Fourth Amendment subject by subject and gives an answer to each of them in their order. The topics include the following: definition of the family, the new $U$ ) article regarding the communist past, recognition of churches, campaign advertisements of political parties published by the media, restrictions on the freedom of expression, autonomy of higher education institutions, "tying the students down" in respect of binding them to work in Hungary after their graduation for a period of time, criminalization of homelessness, judicial independence (status of the Chair of the National Office for the Judiciary, and her jurisdiction of relocating judicial cases), changes

5 See with commentaries: Gomien, D.: Short Guide to the European Convention of Human Rights. Council of Europe Information and Documentation Center, Budapest, 1994. (translated by Polt, P.)

${ }^{6}$ Being the first to do so out of the former communist states.

7 CDL-AD(2012)001. sz., CDL(2011)016. sz., CDL(2011)001. sz., CDL-AD(2012)001. sz., CDL-AD(2012)009. sz., CDL-AD(2012)020. sz., CDL-AD(2012)004. sz. Opinions.

8 These criteria are highlighted in Point 12 of the Opinion.

9 Experts of the government found several "arguable solutions" in the amendment - see Opinion Point 11.

10 Opinion Point 13. 
in the legal status and competence of the Constitutional Court, imposition of special taxes due to decisions of the Constitutional Court or European Court of Justice, which would result in budgetary consequences. Finally, the Commission took a position summarizing the current situation of constitutionalism in Hungary.

From amongst the subjects examined by the Opinion, we shall not analyze Article U) dealing with the communist past, for - in agreement with the Commission - we consider it as a political declaration, ${ }^{11}$ and therefore not a legal norm. However, examination of the other subjects may prove to be an essential resource in presenting the current state of public affairs in Hungary.

4. The Resolution of the European Parliament (hereinafter: Resolution) is not restricted in its scope to the Fourth Amendment, but evaluates the trend of Hungarian constitutionalism in its entirety, and in particular, focuses on the situation of fundamental rights. The Resolution stresses that since 2010, in order to reshape the constitutional order of the country, the former constitution was amended twelve times in a year, and Fundamental Law was amended four times; these have caused a substantial change in the institutional and legal environment of Hungarian public and partly private law. ${ }^{12}$

Furthermore, the Resolution tackles not only the Hungarian situation, as statements were also made concerning other Member States. Even, the closing chapter of the Resolution, ${ }^{13}$ under the title of "Recommendations" calls on all Member States to promote the Union's common values and guarantee the genuine area of freedom, security and justice. The Resolution compares the Hungarian legislative process with the Union's law, however, due to the parallel nature of the protected values by the EU and the documents of the European Council, the overlap is necessary.

The Resolution points well beyond the Opinion of the Venice Commission by presenting and evaluating the "Hungarian norms and practice" - thus defining its mission wider. Undoubtedly, both the Opinion and the Resolution, as well as the preceding inquiry were triggered by the Fourth Amendment: the very subject of this inquiry and evaluation is the totality of the Hungarian constitutional system. Therefore, the Resolution follows a different course, than the Opinion, which examines the Fourth Amendment subject by subject. The Resolution follows a chronological order to show the Hungarian events, and does so with utmost accuracy, precise recall of the events-occurrences, using impartial phrasing, which might be very edificatory for the future of Hungary, informative for the history of the country and important for the constitutional development of this and other Member States of the EU.

The Fourth Amendment shows the roughness of our constitutional development, and even compared to Fundamental Law itself, or its prior three amendments, no disguise was given for the better appearance, it is so to say "swaggering". It is no wonder then, that both standpoints: the Opinion and the Resolution - overlap sometimes, the latter Resolution clearly citing the Opinion several times ${ }^{14}$ - are very similar, or sometimes exactly the same in result. However, whereas the Opinion was restrained to the subjects of the Fourth Amendment basically, the Resolution demonstrates the chain of events in their chronological order: this gives a clear picture of the distortion process in terms of fundamental values

11 Opinion Point 23.

12 Resolution Chapter I - Background and main issues at stake, Point V.

13 Resolution Points 59, 62-65.

14 See e.g. Chapter I. CL point of the Resolution. 
(particularly Art. 2. of TEU), ${ }^{15}$ lasting from the summer of 2010 and being widely criticized around the world. One might have reservations about the well-foundedness of these critiques, naturally. What is important, however, for our purposes, is that we see a clear picture of the opinion of these two respected institutions; how does the Hungarian constitutional system operate, what is its overall status, what is the special role of Fundamental Law in this system, with special regard to the fact that the competence of the Constitutional Court is strictly limited - and this limitation is accepted by the 12/2013. (V.24) AB decision. ${ }^{16}$

\section{B) Assessment of the institutions of the Fourth Amendment}

5. The definition of family is given by Art. L) para. (1) as amended by the Fourth Amendment: Family ties shall be based on marriage - as the union of a man and a woman - or the relationship between parents and children. Antecedent to the new text, the Constitutional Court annulled ${ }^{17}$ the renewed - narrow - notion of family, however, the Fourth Amendment brought this change into Fundamental Law; hence the Constitutional Court can no longer determine this notion as unconstitutional. The Opinion concluded that the European Court of Human rights interpreted Art. 8 of the European Convention on Human Rights broadly: in addition to the marriage and parent-child relationship the right to family life is included into that Article. ${ }^{18}$

In September 2013, the Parliament amended Fundamental Law, now for the fifth time; however, this observation remained unresolved - the Fourth Amendment's definition of family being unchanged.

6. A clear example of the incoherence within Fundamental Law is the state of regulation related to the churches. Even though Art. VII declares the freedom of thought, conscience and religion, the Fourth Amendment adds to and modifies this section and the freedom of establishment is limited by vesting the decision (on establishment) to Parliament.

Legislative requirements related to the recognition of churches had run a turn before the Constitutional Court and were found unconstitutional, thus being partly annulled. The Court argued that in part the decision on establishment becomes subject to a political decision; and partly the absence of remedy was criticized. The Fourth Amendment incorporated the annulled text to Fundamental Law, of which the Venice Commission formulated its opinion: the text is inaccurate, uses broadly formulated criteria, gives a very broad margin of appreciation, discretion to the Parliament; hence, this fundamental right protected by the European Convention on Human Rights Article 9 para. (1) - is still subject to political decision. Again, the Opinion criticized the continuing lack of legal remedy. ${ }^{19}$

The Resolution stresses that Fourth Amendment was adopted only two weeks after the decision of the Constitutional Court, and by embodying the unconstitutional regulation into

15 These being: Human dignity, freedom, democracy, equality, rule of law and respect for human rights.

16 Since I tackle the Fourth and Fifth Amendments in this essay, I lay emphasis on the Opinion of the Venice Commission and refer to the relevant articles of the Resolution from this viewpoint. However, I will not avoid addressing those issues of the Resolution that are independent from the Fourth Amendment.

17 See 43/2012 (XII.20.) AB decision; <<http://public.mkab.hu/dev/dontesek.nsf/0/065D43D11 83D5A48C1257AE8004C12E8?OpenDocument $>>$

18 Opinion Point 20.

19 Opinion Point 36. 
Fundamental Law, the decision was surpassed. ${ }^{20}$ According to the Resolution this may adversely affect the duty of the state to regulate religions and views in a neutral and nonbiased way.

The Fifth Amendment responded to this objection, amending the text of the Fourth Amendment, however, according to the Amendment the essence shall not be changed [Art. VII para. (2)-(4)]. The focus was shifted to a new category: "co-operation". Churches in co-operation with the state shall be considered as "established churches", with the Parliament still deciding over this issue. Established churches may have special rights (privileges) - this presumably covers the state budget to support and donate the maintenance of social, educational institutions etc. Hence, the important issue will continue to be decided by the political sphere; with no legal remedies mentioned.

7. Fundamental Law declares the freedom of expression [Art. IX para. (1)], however it is limited by the Fourth Amendment in one important feature.

The limitation of electoral advertisements of political parties [Fundamental Law Art. IX para. (3)] was a widely criticized rule of the Fourth Amendment, because commercial media was excluded from the potential publishers of political advertisements. This is a rule that - again - defies a previous Constitutional Court decision, ${ }^{21}$ which annulled a particular rule of the Act on electoral procedure with the same content; being incorporated into Fundamental Law by way of the Fourth Amendment with no change in content.

According to the Opinion of the Venice Commission, the fundamental right to freedom of expression - in violation of the European Convention on Human Rights - is violated: this rule deprives the opposition-to-be of the possibility of publishing their opinion. Moreover, the aim of the rule is clear: due to the fact that this is an ephemeral detailed rule, which may often be the subject of amendment, it is not appropriate for incorporation into Fundamental Law. Legislation of this level might deprive the Constitutional Court of the competence to review the constitutionality of laws within this subject-matter. ${ }^{22}$

The Resolution of the European Parliament emphasizes that such a regulation might endanger the requirement for balanced information, which is accompanied by the centralization of public service broadcasting and its institutions, and may result in a distortion of the media market. ${ }^{23}$

The Fifth Amendment responds to this criticism, as well, but not in an effective way. According to the new rule, commercial media shall have the right to publish electoral advertisements, however, free of charge only. This condition practically makes this alternative impossible, thus this "complicated" solution practically leaves the original ban unchanged, though it will be guaranteed by the condition of gratis advertisements. Thus, the lifting of the ban is attached to a condition that, in fact, maintains the ban. Therefore, the Fifth Amendment evades the criticism of the Venice Commission and European Parliament.

The incoherence within Fundamental Law is rather obvious: The fundamental right is guaranteed in Art. IX para. (1), however, its content is substantially limited in para. (3).

8. Freedom of expression is also violated by the rule tackling "hate speech" in the Fourth Amendment [Art. IX para. (5)]. Again, it is a former rule from the Criminal Code, codified into Fundamental Law, that previously has been held unconstitutional by the

${ }^{20}$ Resolution Chapter I. Point CP, see further: Chapter II. Point 56.

${ }^{21}$ See 1/2013 (I.7.) AB decision <<http://public.mkab.hu/dev/dontesek.nsf/0/9C05BC19C310A 316C1257ADA0052476B?OpenDocument $>>$

22 Opinion Points 45-47.

${ }^{23}$ Resolution Chapter II. Points 45 and 50. 
Constitutional Court. ${ }^{24}$ This particular rule - which puts the dignity of the Hungarian nation under penal protection - was subject to serious criticism from the Commission: the Opinion almost lectures the legislator of the constitution when points out that only human persons have dignity. ${ }^{25}$ Qualifying the violation of the dignity of the Hungarian nation serves the purpose of eliminating, gagging the criticism towards public figures.

The Fifth Amendment does not tackle this issue.

Thus, it seems that Hungarian Fundamental Law guarantees the fundamental right to a freedom of expression; it declares substantial limitations within the very same article. Internal incoherence is at hand.

9. The violation of the autonomy of universities [Fundamental Law Art. X para. (3)] was declared in a decision of the Constitutional Court, ${ }^{26}$ that decision annulled the legislative provisions which placed the economic governance of universities under government control. The Fourth amendment lifted this rule to Fundamental Law, again. Yet again, the Venice Commission pointed out that the impugned rule does not necessitate a constitutional level to regulate, a simple act would do. ${ }^{27}$ Hence, changing the level of regulation - once more - has the aim of exempting this subject from the scrutiny of the Constitutional Court.

The Fifth Amendment does not deal with this issue.

Although Art. X para. (1) and (3) declares freedom of education - implying autonomy of the institutions of higher education - the new third sentence in para. (3) makes this illusory, though.

10. The binding of university students to the country, was covered by a rule that laid down conditions to state support of higher education as a period of working or being entrepreneur in Hungary [Art. XI para. (3)] and this rule was, yet again, a rule annulled, being declared unconstitutional by the Constitutional Court. ${ }^{28}$ The rule was incorporated into Fundamental Law by the Fourth Amendment. The Opinion again sees through the disguise $^{29}$ and declares that this rule is not on the constitutional regulation level - the goal is the exclusion of the Constitutional Court's review.

The Fifth Amendment does not tackle this issue.

While Article XII of Fundamental Law declares the freedom of choosing one's occupation, work; this right is substantially limited by Art. XI para. (3) - enacted by the Fourth Amendment.

11. The rule which qualified homelessness as misdemeanor was again annulled by the Constitutional Court, ${ }^{30}$ claiming that it does not comply with the constitutional criteria for criminal sanctions, because it is not a penal but social issue, which has to be dealt with using social policy and social laws. It was also enacted into Fundamental Law [Art. XXII

${ }^{24}$ See 95/2008 (VII.3.) AB decision <<http://public.mkab.hu/dev/dontesek.nsf/0/FC794F16CC E9B140C1257ADA00526A21?OpenDocument $>>$

25 Opinion Point 53.

${ }^{26}$ 62/2009 (VI.16.) AB decision <<http://public.mkab.hu/dev/dontesek.nsf/0/7F15EBE3EF138 9C7C1257ADA00525D94?OpenDocument $>>$

27 Opinion Point 57.

${ }_{28}$ 32/2012 (VII.4.) AB decision <<http://public.mkab.hu/dev/dontesek.nsf/0/780CA328B83B30 4BC1257ADA00524DBC?OpenDocument $>>$

29 Opinion Point 61.

30 38/2012 (XI.14.) AB decision <<http://public.mkab.hu/dev/dontesek.nsf/0/1C19F4D0CFDE3 2FBC1257ADA00524FF1?OpenDocument $>>$ 
para. (3)] by the Fourth Amendment. The Venice Commission repeats the objections: it is not that kind of detailed rule requiring constitutional level: the purpose is to exclude the review of the Constitutional Court regarding rules on this subject. ${ }^{31}$

For that matter, the Resolution is also concerned with the criminalization of homelessness. ${ }^{32}$ The Fifth Amendment does not deal with this issue.

12. As to the independence of the judiciary, it triggered the criticism of the Commission and European Parliament in two aspects.

12.1. In its previous reports, ${ }^{33}$ the Commission repeatedly criticized the exceptionally broad authority of The President of the National Judicial Office (Fundamental Law $\S 25$ ) and legal regulation placing judges under direct dependence from the president. Furthermore, the Commission commented on the complete lack of the President's responsibility and accountability. ${ }^{34}$ The Venice Commission was disappointed to state that the Fourth Amendment disregarded these comments and contrary to them, the status of the President was affirmed in Fundamental Law. ${ }^{35}$ Doubtlessly, it is a step back from the previous opinions of the Commission.

The Fifth Amendment fails to address the criticism of the Venice Commission.

12.2. The right of the President to transfer cases to courts other than those prescribed by the Act was sharply criticized by the Venice Commission. ${ }^{36}$ The Resolution also criticizes the lack of objective, normative criteria regarding the selection of transferred cases. ${ }^{37}$

This possibility was deleted from Fundamental Law by the Fifth Amendment. In the end, it seems as though the criticism was heard. However, if we take into account, that the aforementioned rights of the President - which lead to the legal and actual dependence of judges - remained untouched, then it is understandable that there is no need to maintain the right to transfer cases: the suspicious aim is obtainable without this particular institution.

12.3. Whilst Fundamental Law declares the independence of the judiciary [Art. 26 para. (1)], another rule [Art. 25 para. (5)-(6)] reinforces the competences of the President of the National Judicial Office - threatening their independence - on a constitutional level.

13. The Venice Commission confronts the issue of the status and competence of the Constitutional Court limited by the Fourth Amendment in a voluminous part, that shows the importance of this worrisome issue. ${ }^{38}$

I ought to expressly state my opinion that the concrete limitations of competence should not fully depict the limitation regarding the status of the Constitutional Court, where the phenomena of incorporating such rules into Fundamental Law has previously been declared unconstitutional or shown ephemeral political interests. The latter method - even though it does not directly concern the competence of the Court - shall limit the Constitutional Court's legal possibilities of a review, the subject-matter of the review shall also be substantially limited, thus narrowing the remedies of citizens. Therefore, in terms of

31 Opinion Point 65.

32 Resolution Chapter II. Point 55.

33 CDL-AD(2012)001. Opinion on Act CLXII of 2011 on the Legal Status and Remunaration of Judges, and Act CLXI of 2011 on the Organisation and Administration of Courts of Hungary; adopted by the Venice Commission at its Plenary Session (Venice, 16-17. March 2012 para. 118.

${ }^{34}$ See in the Hungarian literature: Vörös, I. (2012, 118-137.)

35 Opinion Point 69.

36 See Opinion Point 74.

37 Resolution Chapter I. Point AZ.

38 Opinion Point 77 sqq. 
its status, it is more and more doubtful, that the Constitutional Court will be able to fulfill its function, as the ultimate protector of the Constitution.

13.1. First and foremost, the Opinion criticizes the now consistent method, ${ }^{39}$ whereby those rules that have been declared unconstitutional are inserted into Fundamental Law. The reasoning of the Government, namely that the Fourth Amendment and its insertion into Fundamental Law was required due to the annulment of the Transitional Act of Fundamental Law by the Constitutional Court, was simply rejected by the Opinion: they explain that this is plainly untrue. ${ }^{40}$ Neither the churches, nor the homeless, nor the concept of the family, nor the limitation of electoral advertisements was subject of the Transitional Act. Indeed, the Government reacts on a regular basis to the Constitutional Court's annulling decisions by inserting those rules into Fundamental Law. According to the Opinion, it is certain that Parliament has the right to amend Fundamental Law, however, this may not result in invalidating the democratic system of checks and balances. This method became regular, thus, indeed we should add, that it is limiting the competence of the Constitutional Court, even without expressly limiting its authorization. This procedure undermines the role of the Constitutional Court in the constitutional, public legal system, thus violating the three pillars regulated in the Statute of the Council of Europe: respect for human rights, rule of law and democracy, and at the same time endangering the separation of powers. ${ }^{41}$

13.2. Regarding the nullification of the former decisions of the Constitutional court delivered under the 1989 Constitution - (Fundamental Law Closing Provisions Point 5) the Opinion sees the danger of legal uncertainty. According to its statement, those decisions contained very important guidelines not only for the Constitutional Court and its future decisions, but also for the ordinary courts. In these circumstances the Fourth amendment and this rule creates legal uncertainty. On the other hand, this amendment is a clear sign that the Government is intent on limiting the competence and legal status of the Constitutional Court on a regular and systematic basis. ${ }^{42}$

According to the Resolution, the ban on the citation of the former constitutional Court decisions is "extremely" concerning. Those decisions were esteemed by the Resolution: they contain an "entire system of founding principles and constitutional requirements", including the application of Union and human right norms. Thus, it is particularly concerning that other courts may not be able to base their decisions upon the previous case law of the Constitutional Court. ${ }^{43}$

13.3. Further troubling circumstances are enlightened by the Venice Commission in its Opinion, when analyzing the governmental reaction to the 45/2012 (XII.29) AB decision, ${ }^{44}$ in which the Constitutional Court expressed its resolve to review the amendment of the constitution in particular situations. The new rule under the Fourth Amendment [Art. 24 para. (5)] incorporates this subject into Fundamental Law so as to allow review only upon a procedural basis. Hence, this unregulated topic shall be constitutionalized by the Fourth Amendment in a way that bars the Constitutional Court from substantial review according

39 According to the wording of the Commission: consistent pattern (Opinion Point 81).

40 Opinion Point 79.

41 Opinion Point 87.

42 Opinion Points 90 and 98.

43 Resolution Chapter II. Point 19.

44 See infra Chapter I. Point 2 and fn. 6-7. 
to the test set forth in the above-mentioned decision of the Constitutional Court. According to the Resolution this new rule weakens the system of checks and balances. ${ }^{45}$

In its communication to the Commission, ${ }^{46}$ the Hungarian Government attempted to prove that this new rule actually broadened the competence of the Constitutional Court, since it regulated a till then non-regulated issue of competence. However, the Commission - with a view to the detailed reasoning of the $45 / 2012$. AB decision, to which the Fourth Amendment is definitely opposed - pointed out that this is simply untrue. It is embarrassing to read the diplomatic, polite wording of the Commission: "the argument ... cannot be followed", ${ }^{47}$ which conveys the deprecating opinion of the Commission. It is particularly interesting for the Commission that this amendment neglects the remark of the Constitutional Court which draws attention to the international duties of Hungary, particularly those, arising from EU membership.

13.4. The Commission expresses serious concerns regarding the long-lasting and total denial of the competence of the Constitutional Court regarding budgetary matters [Art. 37 para. (4)-(5)]. ${ }^{48}$ Paragraph (4) appeared in the original wording of Fundamental Law, and it excluded the review of the Constitutional Court in budgetary, taxation matters until sovereign debt falls to under $50 \%$ of gross domestic product. As long as this situation does not arise, the Court may review the constitutionality of budgetary Acts for violation of only such fundamental rights, that are practically not possible. These rights are the following: human dignity; privacy (protection of personal data); freedom of thought, conscience and religion; fundamental rights related to the Hungarian nationality.

Since decreasing sovereign debt is dependent on governmental economic policy, it is rather obvious that all governments are free to decide when to "give" competence to the Constitutional Court for constitutional review of such Acts.

However, the Fourth Amendment [Art. 37 para. (5)] goes even beyond this, when - in extremely confusing language - it provides, that those legislative acts regarding the budgetary or taxation issues that have been passed under difficult budgetary circumstances (namely sovereign debt surpassing $50 \%$ of GDP) "shall be applicable for this period [?] even if sovereign debt does not exceed fifty per cent of gross domestic product". The Opinion emphasizes that this provision prolongs the application of supposedly unconstitutional legal regulations - for an unforeseeable period of time.

The Resolution expresses further concerns: limitation (rather: termination - in my opinion) of the supervisory powers of the Constitutional Court over the budgetary competences of the Parliament and Government, will endanger more fundamental rights. ${ }^{49}$

At this point, the Venice Commission - using very sharp phrasing - summarizes its position towards the Fourth Amendment and its relation to the Constitutional Court. The Opinion $^{50}$ "again repeats its serious concern about the limitation of the competence of the Constitutional Court to review legislation". Constant shielding of potentially unconstitutional laws from review is a "direct attack" on the supremacy of the Fundamental Law of Hungary. The Fourth Amendment has given up the link of that provision due to continued budgetary difficulties and thus has institutionalised this exception (namely the limitation).

45 Resolution Chapter II. Point AP.

46 See supra Point I.2.

47 Opinion Point 108.

48 Opinion Point 109.

49 Resolution Chapter I. Ponti AO and Chapter II. Point 15.

50 Opinion Point 113. 
This results in a reduction of the position of the Constitutional Court as guarantor of Fundamental Law and its principles.

The Resolution repeats these concerns word-by-word. ${ }^{51}$ The Constitutional Court can no longer fulfill its role as the supreme body of constitutional protection. Therefore, the Resolution evaluates the incorporation of formerly unconstitutional Acts into Fundamental Law as undermining the supremacy of Fundamental Law over the legal system, hence suggesting the deletion of such regulations from Fundamental Law. ${ }^{52}$

The Fifth Amendment of Fundamental Law does not deal with this issue.

13.5. Competence of the Constitutional Court was again excluded by the Fourth Amendment [Art. 37 para. (6)] for such a particular situation - assuming that sovereign debt surpasses $50 \%$ of GDP - when a high court (Constitutional Court, European Court of Justice or other court) delivers a decision laying a monetary charge on the Hungarian state. For that occasion, the amendment codified the possibility of levying a special tax; a constitutionalized rule that excludes the possibility of constitutional review and thus annulment.

The Opinion suggests that such a rule might lead to aversion against judicial decisions - let us call a spade a spade: incitement, destroying the prestige of decisions -, which will decrease the social approval of the decisions. Thus, placing judicial decisions in such a context is contradictory to the rule of law as regulated in Art. B) para (1) of Fundamental Law.

The Resolution expresses serious concerns about the compatibility of this rule with the European Union's law. ${ }^{53}$

Even though the Fifth Amendment lifted this rule, however, at the same time it was incorporated into Act 194 of 2011 on the economic stability of Hungary, which needs a two-thirds majority of the members of Parliament to be amended. Thus the situation remained unchanged in a way, since practically this rule can be amended only with extreme difficulties. However, constitutional review is allowed for now. For that matter the Government only has to prove for the constitutionality of the law that the amount in the budget is "not sufficient" to meet the obligation of the judicial decision. However, the Constitutional Court will have no competence within a foreseeable period to review matters of taxation, ${ }^{54}$ hence the possibility of levying this tax remains. Again, a lopsided result: the Opinion of the Venice Commission and criticism of the European Parliament were taken into consideration but in the end they were ignored indeed.

14. In closing, the Venice Commission gives a summarizing evaluation of the situation of Hungarian constitutionalism. ${ }^{55}$ There are three particularly serious concerns named by the Opinion.

Firstly, the Opinion of the Commission states that the great numbers of cardinal laws poses "a serious threat to democracy", ${ }^{56}$ even though the Venice Commission repeatedly found this situation alarming - without any substantial success. Since this situation will

51 Resolution Chapter II. Point 17.

52 Resolution Chapter II. Point 5 and Chapter III. Point 72 first subpara.

53 Resolution Chapter II. Point 20.

${ }^{54}$ See this essay Chapter II. Point B) 13.4. and fn. 57.

55 Opinion Chapter VI.

56 Opinion Point 129. 
cripple the work of future parliaments, elections would become meaningless, ${ }^{57}$ which is a serious violation of Article 3 of the First Protocol of the European Convention on Human Rights. The Resolution of the European Parliament also disapproves the application of such high numbers of cardinal laws, which undermine the principles of democracy and rule of law, thus decreasing the chances of future governments to respond to social changes. ${ }^{58}$

On the other hand, the Opinion states that the constitutional amendments were denigrated to be tools of daily politics, when such particular rules were constitutionalized that do not fit into Fundamental Law (criminalization of the homeless, state support of university students in exchange for a period of working in Hungary, financial control of universities). The constitution is not a simple political declaration, it should not be part of petty political games. Reviewing the process of drafting Fundamental Law, the Venice commission found that it was not transparent enough. Ammending Fundamental Law four times is a worrying sign of an instrumental attitude towards the constitution as is the resort to the exceptional two-thirds majority in constitution-making without a genuine effort to form a wide political consensus and without proper public debates (as happened in Romania - adds the Commission). ${ }^{59}$ Drafting a constitution or amending it is not a simple arithmetic issue, it is not the automatic possibility of the two-thirds parliamentary majority; such an act should record neutral and generally accepted rules for the political process.

The Resolution is of the Opinion, too, that the systematic amending of Fundamental Law declares nothing but actual political will. ${ }^{60}$

On the third count, the Opinion emphasizes that the Fourth Amendment will conserve the defects of the Hungarian constitutional system, especially with the systematic decrease of the supervisory powers of the Constitutional Court by means of systematic incorporation of unconstitutional laws into Fundamental Law. Within this constitutional system the adoption of constitutional and daily politics will merge; a phenomenon that is irreconcilable even with Hungarian Fundamental Law and also with the standards regulated in the documents of the European Council - especially in respect of democracy, the rule of law (including separation of powers) and the protection of human rights. ${ }^{61}$

The Resolution summarizes its concerns and deems that the systemic and general trend of repeatedly modifying the constitutional and legal framework in very short time frames, and the content of such modifications, are incompatible with the values referred to in Art. 2 TEU, Art. 3, para. 1, and Art. 6 TEU, and deviate from the principles referred to in Art. 4, para. 3, TEU; hence in toto it results in a clear risk of a serious breach of the values referred to in Art. 2 TEU. ${ }^{62}$

57 Opinion Point 133. "Elections ... would become meaningless if the legislator would not be able to change important aspects of the legislation...". The Resolution has almost the same wording in Chapter II. Point 8. - "Cardinal laws" are act which need two-thirds majority of MP's vote therefore the amendment by later legislation is extremely difficult.

58 Resolution Chapter II. Point 8.

59 Opinion Point 136.

60 Resolution Chapter II. Point 17.

61 Opinion Points 141-147.

62 Resolution Chapter II. Point 58. 


\section{III.}

\section{2/2013 (V.24.) AB DECISION OF THE CONSTITUTIONAL COURT ${ }^{63}$}

1. These problems were realized not only by Hungarian legal literature ${ }^{64}$ but the Commissioner for Fundamental Rights (hereinafter: ombudsman) launched a procedure at the Constitutional Court.

The petition of the ombudsman stated unconstitutionality of the Fourth Amendment of Fundamental Law on two counts. Pro forma, he alleged invalidity due to public legal reasons; pro meritis he referred to the internal incoherence caused by the Fourth Amendment. Formal unconstitutionality stems from the fact - as he alleged - that the Parliament, in plenary session, has failed to discuss those substantial proposals for amendment that were lodged by the relevant commission. Even though this might have been in accordance with the Standing Orders of Parliament, ${ }^{65}$ the rule of law [Art. B) para. (1) of Fundamental Law] has been violated, particularly the possibility of an open debate of public issues, a thorough inquiry of the debated issues, the freedom of speech of the Members of Parliament.

Regarding the merits of the unconstitutionality, the petition also stated invalidity due to public legal reasons, stating the following position: the Fourth Amendment has brought incoherence - contradictory rules within Fundamental Law - into the constitution, thus, it shall be null and void. The ombudsman referred to Art. 24 para. (1) of Fundamental Law (the Constitutional Court is the supreme protector of Fundamental Law) as a remarkable argument; a line of reasoning that appeared in the opinion of the Venice Commission and the resolution of the European Parliament, later. He further referred to Art. R) para. (1) of Fundamental Law (Fundamental Law shall be the foundation of the legal system of Hungary). Therefore, no amendments shall be incorporated into Fundamental Law that may cause incoherence, internal contradiction, thus destroying the unity of it. Even the competence of Constitutional Court was derived from the aim of Art. 24 para. (5) of Fundamental Law; that is the competence of the Constitutional Court to abolish internal contradiction. Particularly, as detailed in the petition, the Fourth Amendment brought such elements into Fundamental Law, that were annulled as lower Acts by the Constitutional Court ("over-constitutionalization"). ${ }^{66}$

2. The first, formal argument, - invalidity due to public legal reasons - was rejected by the Constitutional Court (hence the petition was refused in this part), because the Fourth Amendment was passed in complete accordance with the Standing Orders of Parliament, and re-opening the debate in the details (second reading) was possible. Thus, the closing debate was omitted without a motion for such a debate. Competence of the Constitutional Court was based on the new Art. 24 para. (5) - amended by the Fourth Amendment under review! - which regulated the review of the constitution by the Constitutional Court: the

${ }^{63} \mathrm{http} / / /$ public.mkab.hu/dev/dontesek.nsf/0/1E09722E15EB5DA0C1257B5D001B9851?Open Document

${ }^{64}$ See supra footnote 7.

65 Though quite outdated, available in English at $<<$ http://www.parlament.hu/hazszabaly/ resolution.htm $>>$

66 Particular cases will be detailed in accordance with the Opinion of the Venice Commission and the resolution of the European Parliament, see infra II. B) point. 
supreme body may investigate only procedural issues and is barred from entertaining substantial arguments. ${ }^{67}$

(This Rule was a reflection of the 45/2012 (XII.29.) AB. Constitutional Court decision, ${ }^{68}$ no rules in Fundamental Law existed before. In this Decision, the Court warned that subsequent amendments - three in a one-year period - might necessitate substantial review of those amendments in order to secure the coherence of Fundamental Law. ${ }^{69}$ This purpose of substantial review was barred by the Fourth Amendment by giving particular rule to the review of constitutional amendments, and at the same time restraining it to procedural issues.)

Assessing the other argument, based on invalidity due to public legal reasons resulting from incoherence ${ }^{70}$ within Fundamental Law, the Constitutional Court took the position that it is concerned with substantial issues, not formal ones. However, as a result of the Fourth Amendment [Art. 24 para. (5)], the Constitutional Court has no competence to consider this issue. Within the framework of separation of powers, the power of the Constitutional Court is limited as well, hence review of the amendments on the merits cannot be conducted without explicit authorization. According to the Court, this second part of the petition under the guise of the formal argument of invalidity due to public legal reasons - asked for a substantial review indeed, a competence that is unavailable to the Constitutional Court after the Fourth Amendment. ${ }^{71}$

However, the Court - obiter dicta - pointed out that future constitutional review of the legislation will naturally consider the coherent system of interdependent fundamental rights, and the limitation of the legislative power as regulated in Arts E) and Q) of Fundamental Law, which is connected to our international obligations in general and Hungary as an EU Member State. For these reviews it is proper that the Constitutional Court shall interpret and apply Fundamental Law as a coherent system.

3. The argumentation of the Court is tilted in two aspects. On the one hand, the very subject of the review was the Fourth Amendment, but still the Court delivered its decision based on the competence regulated in Art. 24 para. (5) of Fundamental Law, as amended by the Fourth Amendment itself.

On the other hand, the Court considers the non-reviewed, hence not excluded incoherence to be resolvable in abstracto, offering its future interpretation without giving it a try; even though that would be the only possible way to give guidance to resolve the actual incoherencies brought up by the petition. In other words, the decision has not dispelled the concerns related to the issues raised by the petitioner; as to whether they are even solvable, and if so, with what method and what actual interpretation. Ensuring coherence with yet to come interpretation will disappear in the distant fog of the future, since such decisions will be delivered only after further legislation requires it. The constitutional situation is then, indeed, one where the suspicion of incoherence still remains,

${ }^{67}$ See 30-33 points of the Decision.

$68 \mathrm{http} / / /$ public.mkab.hu/dev/dontesek.nsf/0/B139EF59DD213D0BC1257ADA00524EC0?Open Document

${ }^{69}$ See Point [82] of the Decision: "the Constitutional Court shall have competence to review such Acts that undo the unity of Fundamental Law; that open the legislative domain and content of Fundamental Law and which abstract the competence of the Constitutional Court" (translation of the content by the author).

70 Examples infra in Chapter II. Point B).

71 See $41-43$ points of the Decision. 
and resolving incoherence is a theoretical possibility, a topic postponed ad calendas graecas.

4. No wonder the Court was extremely divided, with four concurring opinions and four dissenting opinions being enclosed to the decision. In a sense this showed that the debate caused by the Fourth Amendment will continue, even though the real decision was postponed. However, the fact that this postponement is not ad calendas graecas, is proved by the opinion of the Venice Commission and resolution of the European Parliament.

\section{IV.}

\section{INTERIM EVALUATION}

1. When contrasting the Fourth Amendment of Fundamental Law and its evaluation prepared by the Venice Commission - partly on the mandate from the Hungarian government - and Resolution of the European Parliament we shall base our analysis on facts first. The Venice Commission examined 17 subjects of the Fourth amendment. Among these topics, there is only one issue that has been really resolved: the transition of judicial cases; however - as we saw supra - the system of personal subordination of judges due to the very strong competences of the President of the National Judicial Office holds the potential to undue governmental influence on judges with other methods. Recognition of churches, reformulating the ban on electoral ads, upholding the possibility of levying special taxes are a clear sign - mutatis mutandis after the prime minister - that "the system remains". No other objections - save for one insignificant topic, where the government yielded $^{72}$ - were accepted by the Fifth Amendment.

2. It is apparent then, that the essential elements of the Fourth Amendment are still in force, or the Fifth Amendment "revived" their content using other wording. The diagnosis of the Venice Commission (see: supra Chapter II. Point 10, namely that the Fourth Amendment conserves the defects of the Hungarian constitutional system) is still valid, despite - or more accurately, because of - the Fifth Amendment,

Hence, the "cat-and-mouse game" between the Government and two-thirds majority of the Parliament on the one side, and the European Council, European Parliament and rest of the world on the other side - did not lead anywhere. Both the Opinion of the Venice Commission and Resolution of the European Parliament saw through it and state in plain and clear language: there are systematic constitutional-public legal problems on a regular basis. ${ }^{73}$ It is the whole - and not only one or two pieces of legislation -, the totality of the Hungarian constitutional system that violates Hungarian Fundamental Law, the documents of the European Council (international treaties and statute) and law of the EU.

In light of the aforesaid we must arrive at a necessary question: Is it possible to place the limited wording of a fundamental right into the constitution, as any fundamental right that has been declared earlier might be limited without voiding its content? There is a plausible danger, that this fundamental law will lose its potential to be a standard in constitutional review - since it has lost its measuring function -, thus the fundamental right will be inadequate in fulfilling its primary function: legal protection. Incoherence is

72 Raising the deadline from 30 to 90 days of the procedure of concrete review upon judicial initiation - Opinion Point 115.

73 A particularly sharp phrasing of that can be seen in: Resolution Chapter III. Point 70. subpara. 5. 
apparent. On the one hand: the Constitutional Court will face a decision between contradictory rules within Fundamental Law - e.g. the declaration of freedom of religion and subsequent limitation of it for the churches. The Court will have to choose between the general rule or the particular, limiting rule that should be applied as the standard of constitutional review. Regarding the constitution and its amendments in question, the principle of lex posterior derogat legi priori shall not be applicable. Lex generalis and lex specialis and their relationship is much more detectable in this issue.

On the other hand, incorporating any legal norm - other than a fundamental right into Fundamental Law will result in incoherence, too, since such norms were deemed unconstitutional by the Constitutional Court precisely due to the violation of a particular article of Fundamental Law. As a result of this amendment, the former violated article of the constitution and particular violating rule will stand together in Fundamental Law. These two rules - regulating similar or closely related subjects - will obviously contradict each other, thus excluding each other. One rule might be applied only if the other rule is ignored. The Constitutional Court will face a decision between the former rule or amended, latter rule. This is the very reason, whereby the danger of incoherence becomes a reality, as the Constitutional Court and ombudsman realized. ${ }^{74}$ It is self-evident that the lex posterior principle will be of no remedy in this second case, either.

After the Fourth Amendment, the Hungarian constitutional jurisprudence faces a peculiar dilemma: it must be decided whether the incoherence, caused by a special rule which effectively voided the fundamental right and other constitutional rule - which has been deemed unconstitutional earlier but appeared in the constitution - is resolvable, and if so, by what method?

Henceforward, we attempt to examine the possible ways of resolving this incoherence.

V.

\section{ON THE FUNDAMENTAL RIGHT LIMITED IN THE CONSTITUTION, AND ON SUCH A CONSTITUTION}

\section{Is it a fundamental right if it is limited in the constitution?}

According to Art. I para. (3) of Fundamental Law, by regulating the fundamental right such a special right shall be carved into a stone-constitution, which has substantial content that cannot be limited. Substantial content ("Wesensgehalt") of the fundamental right constitutes a kind of "Ewigkeitsklausel", without which there is no constitution. Any fundamental right has a wording in the constitution that preserves this substantial content limitless. Thus, first step of any constitutional review of any act - other than the constitution itself, obviously shall center on the question as to whether the impugned limitation shall affect the substantial content of the fundamental right - as applied by the Constitutional Court test since 1990. ${ }^{75}$ In case of an affirmative answer, there shall be no further review, and the constitutional process is closed, with the act under review proven to be unconstitutional.

74 42/2012. AB decision, see Chapter I. Point 2 of this essay. Furthermore, see the petition of the ombudsman in Chapter I. Point 1 of this essay.

75 See e.g. 7/1991 (II.28.) AB decision <<http://public.mkab.hu/dev/dontesek.nsf/0/498E98E48 3944FEEC1257ADA00528FAB?OpenDocument $>>$; for further decision see: $879 / \mathrm{B} / 1992$. AB decision, 18/2000 (VI.6.) AB decision. 
In case of a nay, a "loophole" is opened in the second step: it might be still constitutional occasionally, if the limitation is inevitably necessary to enforce another fundamental right or perhaps a constitutional value. In other words: if the other right or constitutional value cannot be enforced in another way than the limitation of the fundamental right (as reviewed), then it might be constitutional. The proper question would be: Is the limitation necessary? In case of a nay, the process stops here, since the limitation was unnecessary. In case of an affirmative answer, the review goes on, with the loophole becoming wider.

As a third step of constitutional review - according to the (above-mentioned) constantly exercised test of the Constitutional Court - we have to ask whether the limitation exceeds the necessary minimum - as legitimized by the aim -, hence is it disproportionate? In case of an affirmative answer, the limitation is unconstitutional. In case of a nay, the limitation is not only necessary, but proportionate as well, thus, the limitation of a fundamental right, incorporated into a different act is - exceptionally - constitutional. (One has to note that not all of the decisions of the Constitutional Court shall apply these perhaps too complicated - steps, that are nevertheless inevitable, therefore necessity and proportionality are often combined.)

Heretofore we presumed the natural assumption that any limitation shall be placed into a different act, other than the constitution itself. This is rather evident, since by phrasing the fundamental right, the constitution codifies the absolute, illimitable standard. Any further regulation concerning the subject of the fundamental right - even limiting it - shall be measured to this standard. Being a standard is the sole function of the fundamental right in terms of its limitation: this is the constitutional framework, thus the barrier for the (majority) legislator. This standard is an etalon, then, just like the etalon of measure of length in Paris: the platinum prototype metre. It is obvious, that this cannot function if it is shorter, say 95 $\mathrm{cm}$; only if it is absolutely accurate: 1 meter.

If one limits the fundamental right within the constitution itself, this fundamental right will be unable to fulfill its function, since it has lost its absolute nature, thus even the standard won't fit. In this case it is unclear, whether the fundamental right shall be interpreted in its entirety, or only in terms of its limited content as regulated in the constitution; thus the content of the fundamental right becomes indefinite. In terms of limiting a fundamental right in the constitution, its formulation in limited form will be $a b$ $o v o$, or an exception to a particular case, lex specialis to the general rule (being limitless upon its formulation); phrasing the fundamental right with doubled content will deprive the fundamental right from its very function. Such a "fundamental right" cannot be a standard anymore.

The Fourth Amendment of Fundamental Law provides several examples in respect of this - as we saw supra.

Declaration of the freedom of opinion, religion, free choice of work and occupation is followed by an exemption that will "nullify" the fundamental right in that particular aspect.

The aim of the government's legal policy - even with its lurking intentions - is clear: most of the acts regulating fundamental rights shall be exempt from constitutional review. The method is clear, as well: any regulation of a fundamental right in the constitution in limited form shall limit, even exclude constitutional review by the fact that this fundamental right was "castrated", deprived of its function, deprived of the very reason that regulated it in the constitution. 
To sum up we might conclude that any fundamental right limited within the constitution is no fundamental right at all. Any limitation of the non-essential content of a fundamental right might be only interpreted within the context of the other limiting act and fundamental right declared in the constitution.

\section{Can we consider a constitution that limits the fundamental rights a real constitution?}

The chapter on fundamental rights is the conditio sine qua non of any constitution. Regulations on organization of the state shall be one-sided, etatist, without guaranteeing fundamental rights. Since all fundamental rules regulated in the Fourth Amendment suffered limitation in their content, these fundamental rights, declared in Fundamental Law - despite the cosmetic surgery of the Fifth Amendment -, are incapable of fulfilling their function; hence the effective text of Fundamental Law does not meet a vital conceptual criterion of the constitution.

\section{Lex specialis derogat legi generali?}

3.1. It is a rather general rule of the civil law codification that the special rule shall overrule the general rule. This is a logical consequence of the structure of civil law, which has been built on the granite foundations of private autonomy. Without private autonomy - which is definitely limitable, being basically a general presupposition, or a regulatory model private law would not be private at all. It is a fundamental assumption in civil law, then, that anything is allowed which is not prohibited by law. The lex specialis derogat legi generali principle is consequential, and results in the codification of dispositivity in the law of contracts.

3.2. In public law, the situation is contrary: Since it covers the constitution of public authority, its organization and operation, private autonomy is irrelevant. Within this sphere, the public (state) authority may act only with and within the authorization of law. Thus, the situation is quite the contrary; a general rule shall invalidate the special rule: any special public law norm may by applied, interpreted within the general boundaries of the general rule. My above-mentioned examples clearly demonstrate that the amended rules of Fundamental Law attempt to invalidate the general rules, and fundamental rights, as lex generalis. Within the public law it is the lex generalis derogat legi speciali principle that must be applied: any special rule might be applied only if it is not violating the general rule.

A good example, according to my opinion, is the recognition of churches (detailed supra in Chapter II. Point 6) as lex specialis, which is special to lex generalis as the general declaration of freedom of conscience and religion within the same article. The Hungarian Constitutional Court shall be required to leave out of consideration this lex specialis, if it is be forced to choose between the two rules.

3.3. This incoherence-dilemma concerning the fundamental rights shall apply to other incoherence in Fundamental Law, as well: constitutional rules other than fundamental rights. Rule of law (Rechtsstaat) as lex generalis must be preferred to the lex specialis of limiting electoral advertisements, even though the freedom of opinion would not have been declared in Fundamental Law. Rule of law must not be invalidated by any special amendment.

3.4. Within the framework of Hungarian Fundamental Law, one must differentiate from the hierarchical point of view for the sake of resolving incoherence. One aspect of this might be applying the lex generalis derogat legi speciali principle - precisely for resolving 
the contradiction between the regulations of Fundamental Law (which may have been included with subsequent amendments). Rule of law, just as human dignity must never be invalidated by any special rule, not even an "exception" regulated in Fundamental Law.

Resolving the incoherence within Fundamental Law - the method of which still remains unprecedented even after the 12/2013 (V.24.) AB Constitutional Court's decision may be attempted by characterizing the norms of Fundamental Law as lex generalis and lex specialis. According to my view, the distinction lies on the borderline of essential/nonessential content as detailed supra. Limitation of essential content shall be prohibited (it makes a fundamental right fundamental, otherwise it is emptied). Limitation of nonessential content shall be admissible in other Acts, in accordance with the criteria of the fundamental rights' limitation test. However, we emphasize that limitation of non-essential content must be placed in another Act, not the constitution itself.

The situation after the Fourth and Fifth Amendments - when the text contains a declaration of a fundamental or other right but immediately thereafter it is limited - raises the issue of a declaration as lex generalis and subsequent limitation as lex specialis as well as their relationship - whether we like it or not. In other words, one must decide, in the case of a collision, the priority between the constitutional rules. The Constitutional Court of Hungary will not escape this path and must solve such incoherence, since it was the Constitutional Court itself, who suggested ${ }^{76}$ in its 12/2013 (V.24.) AB decision, that such problems might be solved by interpreting and applying Fundamental Law as a coherent system. Eventually: habent sua fata libelli - even if books have their fate, it will be no wonder that this challenge of great bravery and responsibility shall be the fate of the constitutional courts.

\section{REFERENCES}

Antal, A. (2013): Alkotmányozási korszakok és technikák (Constitutional eras and techniques). Közjogi Szemle 2013/2.

Chronowski, N.-Csatlós, E. (2013): Juidicial Dialogue or National Monologue? ELTE Law Journal 1(1) http://papers.ssrn.com/sol3/papers.cfm?abstract_id=2332172.

Gomien, D. (1994): Short Guide to the European Convention of Human Rights. Budapest: Council of Europe Information and Documentation Center, (translated by Polt, Péter).

Halmai, G. (2013): Constitutionalism in Hungary: Undermining the Fundamental Law. JURIST Forum, 2013 April 12. http://jurist.org/forum/2013/04/gabor-halmai-hungary-churches.php

Kazai, V. (2013): Kettős nyomás alatt (Under double pressure). Közjogi Szemle 2013/3.

Orbán, E. (2013): Az Alaptörvény paradoxonjai. Átmenetböl? Átmenetbe! (Paradoxons of the Fundamental Law. From Transition? To Transition!). Közjogi Szemle 2013/2.

Smuk, P. (2013): Ostrom vagy felújítás alatt? A véleményszabadság új határai (Siege or under renovation? New limits of the freedom of speech). Közjogi Szemle 2013/2.

Vincze, A. (2012): Die neue Verfassung Ungarns. Zeitschrift für Staats- und Europawissenschaften. 110-129. English translation (not official) of the Fundamental Law can be downloaded from the website of the Government, however, this version has been consolidated with the Fourth Amendment only; <<http://www.kormany.hu/download/e/2a/d0000/THE\%20 FUNDAMENTAL\%20LAW\%200F\%20HUNGARY.pdf $>>$; German translation (not official) of the Fundamental Law can be downloaded from the website of the Government, however this is a version from April 2011, and has not been consolidated with any amendments; $<<$ http:// nemzetikonyvtar.kormany.hu/download/b/00/50000/n\%C3\%A9met-magyar_nyomda.pdf $>>$

76 See this essay, Chapter I. 
Vörös, I. (2012): Grosschmid - reloaded. Tudósítás a jogállamiság határvidékeiről (Grosschmid reloaded. Report from the borderland of the Hungarian Rechststaat). Jogelméleti Szemle 2012/3: 118-137. http://jesz.ajk.elte.hu/voros51.pdf

Vörös, I. (2013): Az alkotmányban korlátozott alapvető jogról és az ilyen alkotmányról. Glossza az Alaptörvény negyedik módositásához. http://fundamentum.hu/sites/default/files/vorosi korkerdes. pdf. 2013.05.15; joint expert opinion of the Hungarian Helsinki Committee, Eötvös Károly Policy Institute and Hungarian Civil Liberties Union on the Fourth amendment, see: http://helsinki.hu/ wp-content/uploads/Appendix_1_Main_concerns_regarding_the_4th_Amendment_to_the_ Fundamental_Law_of_Hungary.pdf

Zeller, J. (2013): Nichts ist so beständig... Die jüngsten Novellen des Grundgesetzes Ungarns im Kontext der Entscheidungen des Verfassungsgerichts. Osteuropa Recht 2013/3: 307-325. 